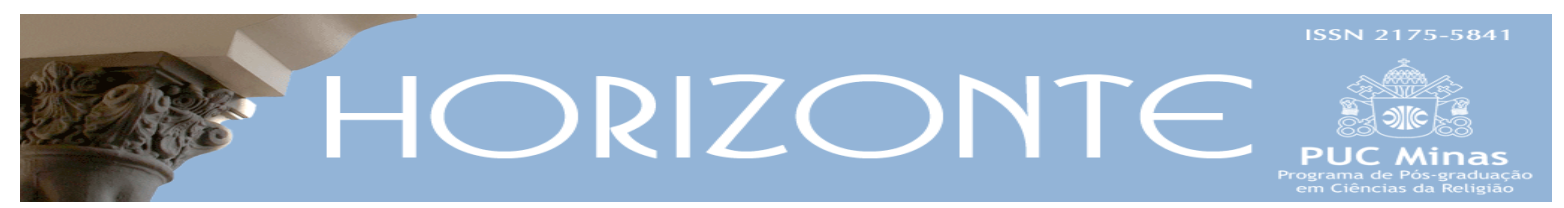

Dossiê: Narrativas Sagradas e Linguagens Religiosas - Artigo Original ๑。을

\title{
Onésimo:
}

\section{um personagem silencioso no Bilhete a Filêmon?}

\author{
Onésimus: a character in silent in the Letter do Philemon?
}

\author{
Joel Antônio Ferreira*
}

\begin{abstract}
Resumo
Pelos Métodos bíblicos tradicionais (Histórico-Crítico e Crítico-Literário) já se estudou o Bilhete a Filêmon, aprofundando o protagonista Paulo $^{1}$ dentro dos modos de produção escravagista romano. Com este artigo atual que usufrui o Método Sociológico pelo Modelo Conflitual/Contradição, a proposta é olhar o mesmo Bilhete a Filêmon, a partir de alguém que foi silenciado no texto original. Como este tipo de Leitura procura detectar as assimetrias, olhar o texto com "suspeição» e dar voz e espaço aos que estão na «margem», o protagonista passa a ser aquele que estava abaixo da pirâmide romana: Onésimo, o escravo. A hipótese deste artigo é que, na prisão, o escravo Onésimo passou do estado da passividade para se tornar um questionador da prática de Paulo. O Apóstolo, então, na crueza da cadeia, sentiu-se tocado. Sua práxis, agora, concretizou-se na luta pela liberdade do escravo. Onésimo teria transformado a conversão de Paulo. Com essa leitura, descobre-se Jesus Cristo na carne do escravo.
\end{abstract}

Palavras-chave: Escravo. Protagonista. Margem. Prisioneiro. Liberdade.

\begin{abstract}
By traditional biblical methods (Historical-Critical and Literary Critic) already studied the Letter to Philemon, deepening the protagonist Paul within the modes of production Roman slave. With this current article enjoyed by the Sociological Method by Model Conflictual/Contradiction, the proposal is to look the same Letter to Philemon, from someone who was silenced in the original text. As this type of Reading aims to detect asymmetries, looking at the text with "suspicion" and give voice and space to those in the "margin", the protagonist becomes the one who was under the Roman pyramid: Onesimus the slave. The hypothesis of this article is that, in prison, the slave Onesimus became the state of passivity to become a questioning of Paul's practice. The Apostle then the rawness of jail, he felt touched. His practice now materialized in the fight for freedom of the slave. Onesimus would have made Paul's conversion. With this reading, we find Jesus Christ in the flesh of the slave.
\end{abstract}

Keywords: Slave. Protagonist. Margin. Prisoner. Freedom.

\footnotetext{
Artigo recebido em 27 de janeiro de 2016 e aprovado em 19 de maio de 2016.

* Possui graduação em Filosofia pela Pontifícia Universidade Católica do Rio de Janeiro (1970) e doutorado em Ciências da Religião pela Universidade Metodista de São Paulo (2001) É assessor do CEBI, assessor bíblico da Arquidiocese de Goiânia e membro da União Brasileira de Escritores.

1 Já foi estudado em um capítulo do livro Paulo, Jesus e os Marginalizados (FERREIRA, 2011, p. 96-103) no livro Gálatas (FERREIRA, 2005, p. 111-114) e no artigo da Fragmentos de Cultura "Não há Escravo nem Livre" (FERREIRA, 2002, p. 717-738).
}

Horizonte, Belo Horizonte, v. 14, n. 42, p. 377-401, abr./jun. 2016 - ISSN 2175-5841 


\section{Introdução}

Um dos menores textos da Bíblia, o Bilhete a Filemon, foi endereçado, também, à Ápia, a Arquipo e à Igreja que se reunia em sua casa (oikía). Ele foi, por um lado, o retrato de fortes assimetrias sociais, políticas e econômicas e, por outro, a sinalização de que algo novo estava acontecendo, por parte dos cristianismos originários. De um lado, o sistema imperial e seus segmentos que reprimiam e sugavam e, de outro, os tantos e tantos grupos e populações oprimidas: eram grupos conscientes que estavam surgindo e se movendo contra o império. Era o tempo do império romano que se baseava no escravagismo, em todos os seus domínios (ROSTOVTZEFF, 1967, toda obra; GIORDANI, 1981, toda obra; GRANT, 1960, toda obra).

Como a interpretação do Bilhete a Filemon será feita a partir da Leitura Sociológica pelo Modelo Conflitual/Contradição, que procura ser, sempre, crítica, será privilegiada a postura de quem estava abaixo da base da pirâmide do esquema romano, dentro do pequeno texto a Filêmon². A leitura crítica quer olhar "por trás" dos acontecimentos narrados por pessoas ligadas a alguma situação de poder3. Querer-se-á escutar a voz de quem estava na periferia das periferias, num ambiente social de total exclusão4.

Muitas vezes, em toda a Bíblia, um texto era narrado a partir da ótica de quem detinha o poder ou pertencia a uma estrutura dominadora. Os intérpretes, tantas vezes, privilegiavam os relatos narrados a partir da posição do narrador não percebendo e nem ouvindo a voz de quem era silenciado, lá na base.

\footnotetext{
${ }^{2} \mathrm{~A}$ força da leitura sociológica pelo modelo conflitual/contradição deu-se na "Escola de Chicago" com Malina e, posteriormente, ela se ampliou no Hemisfério Norte e, especialmente, na América Latina (MALINA, 1986, toda obra; OSIEK, 1989, p. 260-278; ALVAREZVERDEZ, 1989, p. 5-41).

${ }^{3} \mathrm{O}$ hermeneuta, pelo modelo conflitual/contradição, parte das necessidades e situações concretas que os cristãos viviam e assumiam, procurando interpretar a vivência das comunidades cristãs populares que se envolviam num novo modo de ser ekklesía, num processo contínuo de libertação, a partir da comunidade. O Bilhete a Filêmon, por exemplo, se for lido na perspectiva de Paulo somente, apresentará uma ekklesía estruturada, bem no nível de quem está no poder (Paulo, Filêmon, sua casa etc). Porém, se for lido a partir do escravo, sem vez, ele toma outra perspectiva: quem estava debaixo da pirâmide tinha algo a dizer? Essa leitura quer ouvir a voz dos "estraçalhados" pelas estruturas do poder, seja intra ou extra comunidade.

${ }^{4}$ Essa leitura busca o "lugar social" da ekklesía ouvindo a voz dos oprimidos. Ela clareia os grupos e os personagens da "margem", portanto, aqueles que não tinham espaço. Essa leitura quer ouvir a voz daqueles que não tinham voz, porém, que eram os preferidos de Deus (FERREIRA, 2013, p. 46-7).
} 
Por essa leitura, a ótica da reflexão partirá de alguém que estava abaixo da base da pirâmide econômico-social, um escravo. Seu nome era Onésimo. No Bilhete, ele não falou. Não se sabe nada dele, a não ser, que fora um escravo fugitivo e que se encontrava na cadeia. Qual seria a memória desse escravo silenciado? Na narrativa do Bilhete, ele estava sendo favorecido. No entanto, vê-se que ele não foi protagonista. Alguém, de uma pequena superestrutura (Paulo e Timóteo) e um grupo do nível do pequeno poder (Filemon, Ápia, Arquipo e a Igreja) estavam decidindo por Onésimo. Será preciso, com perguntas ao texto, "des-construir" esse mesmo texto, para escutar a voz de um escravo dentro de um modo de produção escravagista romano. Procurar-se-á olhar o "lugar social” de Onésimo, um escravo, um personagem da "margem", portanto, sem espaço e sem voz. A leitura, pelo modelo conflitual/contradição, procura ficar em atitude de "suspeição", exatamente, para tentar descobrir o espaço primordial do esquecido. Procurando escutar a voz do desfavorecido, esse modelo clarifica a opção de Deus pelos pequenos e escravos. O Deus da Bíblia sempre esteve do lado dos fracos. Estes são os preferidos de Deus ${ }^{5}$.

\section{0 projeto de Paulo anterior à comunidade de Filêmon}

\subsection{O texto a Filêmon}

Num primeiro momento, procurar-se-á entender o texto do modo como ele está na Bíblia, ou seja, o Bilhete escrito por Paulo e Timóteo na perspectiva de quem estava à frente da ekklesía (WEGNER, 1997/3, p. 87-9). Na verdade, a referência a Timóteo foi uma gentileza. Paulo, por várias vezes em outras epístolas, colocou outros co-autores, porém, no interio das missivas só se vêem os conceitos e pensamentos de Paulo.

${ }^{5}$ Para se acompanhar a reflexão, será preciso estar com o texto bíblico do Bilhete a Filêmon, ao lado. 
Eis a postura de Paulo, antes do "evento Onésimo": em três momentos, o Apóstolo já havia se manifestado, claramente, contra a escravidão. Lembremos que o modo de produção escravagista romano estava no ápice.

Num primeiro instante, em Gl 3,26-28, um texto das liturgias batismais, possivelmente, elaborado por fiéis estrangeiros, ex-escravos e grupos importantes de mulheres anunciava-se que, em Cristo, "não há mais judeus e gregos, escravos e livres e nem diferença entre masculino e feminino”. Foi um texto revolucionário absorvido por vários grupos dos cristianismos originários (FERREIRA, 2005, p.1112; 88-102). Na mesma Epístola aos Gálatas ele teorizou que foi “para a liberdade, que Cristo nos libertou”. (Gl 5,1.13).

Num segundo momento, em 1 Cor 11,17-34, sobre a "Ceia do Senhor". Dirigindo-se aos cristãos coríntios, habitantes de uma grande metrópole do mundo greco-romano, Paulo teve que denunciar as contradições que aconteciam na hora da celebração litúrgica. Alguns, possivelmente, mais abastados, chegavam antes com a comida e a bebida para a ceia. Antes que viessem os trabalhadores pobres/escravos, os ricos já tinham ceado e se embebedado. Aos pobres restavam as sobras. Na dura reprimenda, o Apóstolo disse para os ricos comerem em casa. (FERREIRA, 2013, p. 135-142). Na liturgia não tinha lugar para as diferenças sociais e econômicas, como faziam os romanos nas suas ceias escandalosas ${ }^{6}$.

Numa terceira oportunidade, em 2 Cor 8,12-13, Paulo apresentou uma proposta real de igualdade. Não podia haver o supérfluo e a ausência de bens, ao mesmo tempo. Todos tinham o direito ao necessário. Foi nessa mentalidade, que ele organizou uma coleta (1Cor 16,1s; Rm 15,26-28; Gl 2,10) para os desabrigados de Jerusalém, sinalizando, a partir do social, a unidade das igrejas. (COMBLIN,

\footnotetext{
${ }^{6} \mathrm{O}$ jantar festivo na sociedade romana imperial era a expressão das desigualdades. A comida e o vinho melhor eram servidos ao anfitrião e aos amigos honoráveis. Em seguida, vinha o convidado principal. O vinho inferior era servido, a seguir, aos clientes menos abastados. Depois, para os libertos. No fundo da sala, era servida a comida menos nobre e o vinho secundário, aos pobres, muitas vezes, assentados em um tapete ou encostados em uma parede. Os escravos, normalmente, comiam depois, muitas vezes, nas áreas de serviço, separados do triclínio (sala de jantar romana) (FERREIRA, 2013, p. 135).
} 
1987, p. 66-70). A partir desses três momentos, fica claro que Paulo, pessoalmente, tinha um "projeto" em torno da liberdade.

Ao enviar o Bilhete a Filêmon, que era um “senhor” (patrão), ele pediu que acolhesse o antigo escravo e que esse deveria ser tratado como se fosse o próprio Paulo ou o seu próprio coração (v. 12). As relações deveriam ser mudadas. Não poderiam viver no nível piramidal e opressor do sistema greco-romano. Paulo foi corajoso.

\subsection{Perspectiva Literária}

Partindo dessa perspectiva, percebem-se alguns dados. a) pessoas concretas aparecem no texto; b) as referidas pessoas são envolvidas na evangelização; c) chama a atenção a figura de uma mulher: Ápia. O autor da missiva se referiu a ela como irmã. d) como Ápia, excluída por ser mulher, aparece o nome, também, de um escravo, alguém, do mesmo modo, excluído no universo greco-romano. O escravo tinha nome: Onésimo.

Como o Bilhete a Filêmon já foi tão estudado, também por nós, em outras oportunidades7, apresentamos um pequeno esquema aqui: no início, temos a introdução, apresentação do bilhete e o anúncio claro do texto, que foi a palavra "amor" (agápe) (vv. 1-8). Em seguida, aparece a força dos conflitos e contradições sociais (vv. 9-13). A seguir (v. 14), surgiu, por parte de Paulo, o respeito à liberdade e à decisão fundamental, por parte de Filêmon. Os versos seguintes (15-17) mostram a separação/união para sempre, frutos da fraternidade que supera a escravidão. Em seguida (vv. 18-22), manifesta-se a tensão econômica que, por muitas vezes, são a causa dos desentendimentos sociais. Os versos finais (23-24) retratam que, de fato, na prisão, estavam Paulo, Timóteo, Epafras e Onésimo. Não fica claro se os outros, Marcos, Aristarco, Demas e Lucas estavam presos ou eram

\footnotetext{
7 Pelos métodos histórico-crítico e crítico-literário, já estudamos Filêmon, a partir do texto e do pensamento sobre a liberdade e escravidão no pensamento de Paulo (FERREIRA, 2002, p. 717-738; FERREIRA, 2005, p. 108-115; FERREIRA, 2011, p. 96-103). Por isso, aqui querer-se-á entender o marginalizado Onésimo, a partir das entrelinhas do texto bíblico que conhecemos.
} 
suporte do lado de fora da cadeia. Como sempre, o texto termina com uma proclamação de fé e coragem (v. 25).

No nível do conteúdo, chama a atenção, em dois momentos, o fato de Paulo referir-se a Filêmon, como uma pessoa envolvida na agápe (amor fraterno: vv 4-7 e 20-22). Esta agápe provoca dois momentos interessantes: Nos vv. 8-14 vê-se que ela destruia o universo da escravidão. Nos vv. 18-19 percebem-se as consequências do universo escravo. O mais pontual é que o Bilhete, na parte central (vv. 15-17), disse que a agápe construia a comunidade. Não foi atoa que, por cinco vezes (1.2.7.16.20), se falou do "irmão/ã". Ainda no nível do conteúdo, o Bilhete sugeriu que se revisse, seriamente, a relação desigual do senhor-escravo (CAÑAVERAL, 1995, p. 46-50). Quando se pediu a Filêmon para que recebesse o antigo escravo Onésimo como irmão, houve uma reviravolta no relacionamento (MÍGUEZ, 1997/3, p. 90-98). Se a agápe quebrava o elo antigo, então, não se podia mais falar de Filêmon como senhor.

Do modo como se lê esse escrito transformador, percebe-se um Paulo que é autoridade, que tem força e age com ela, e que, no protagonismo, fala em nome dos des-autorizados. Paulo tinha, sim, um projeto.

No entanto, quer-se entender se, na masmorra da prisão, no quase tédio e monótono momento de cadeia, na humilhação da falta de liberdade, a postura de Paulo para Filêmon não teve a força dialogal de Onésimo, o escravo, também preso. Ao evangelizar Onésimo, Paulo não foi também evangelizado para ter uma postura contra a escravidão?

\section{0 projeto de Paulo posterior à comunidade de Filêmon}

Num segundo momento, tentar-se-á ouvir, com suspeição, o Bilhete a Filêmon a partir da voz silenciosa de Onésimo, o escravo. É preciso esforçar para des-codificar o Bilhete (as imagens, as categorias) e des-construí-lo, olhando o 
processo dinâmico da vida daquele escravo que aí aparece. Aí se re-codifica e reconstrói. Assim, ir-se-ão manifestando os “conflitos” e “contradições” na leitura, a partir da "margem", ou melhor, do marginalizado.

\subsection{Possíveis tensões do Escravo Onésimo: o ser humano}

Onésimo é o objeto de todo o texto. Pelo menos, duas pessoas estão, como ele, presas: Paulo e Epafras. Paulo, além daqui, já tivera, antes, a experiencia do encarceramento (Fl 1,13-14; 2 Cor 11,23; Rm 16,7). Sua prisão sempre foi uma denúncia ao sistema que prendia e matava.

Não está evidente se Timóteo (v. 1), Marcos, Aristarco, Demas e Lucas (v. 24) também estavam presos. O castigo na cadeia, em qualquer tempo e cultura, gera sempre, tensão, ansiedade, insegurança, desespero e medo. Por que Onésimo foi preso?

a) A tensão de Onésimo era com o patrão Filêmon? Os vv. 18-19 narram que: "se ele o prejudicou em algo ou deve alguma coisa a você, ponha na minha conta. Eu, Paulo, escrevo de próprio punho: Eu pagarei”.

Alguns autores suspeitam que Onésimo teria furtado algo de Filêmon e, por isso, ele foi preso (COMBLIN, 1987, p. 56-61). O que ele teria furtado? Seria algo para suprir as necessidades básicas? O fato é que Filêmon, convertido, tinha escravo. Isso o aliava a Roma. Jogar um escravo, que errou, na prisão era estar cooptado ao jurídico e econômico romano. Diante disso, o que se passava no interior do escravo? Havia ressentimentos contra o patrão? Ele era humilhado, como escravo, pela família de Filêmon? Será que o erro não foi por causa das injustiças cometidas pela casa do patrão?

b) A tensão de Onésimo era com o império romano? O modo de produção que sustentava a economia romana era o escravagismo. Em todas as regiões do império, a maior parte da população era escrava. 
Onésimo era um dos milhares e milhares de habitantes escravizados. Se ele, hipoteticamente, tivesse furtado, não seria para ir aumentando sua poupança para conseguir, no futuro, a liberdade comprada? Ele não agiu assim porque era injustiçado na "casa" de Filêmon? O fato é que o seu ato foi descoberto e ele foi para a prisão. Se o patrão Filêmon tinha escravos, é porque ele falava e vivia a linguagem econômica do império romano. Então, o escravo Onésimo estava preso porque violou a base do sistema imperial ou porque usufruiu, indebitamente, de algo do patrão Filêmon que sobrevivia às sombras imperiais.

c) Como estaria a sua vida, no nível pessoal? Ele tinha família? Tinha filhos? Tinha esposa? O texto não fala nada da existência pessoal de Onésimo, o escravo. O que deduzimos? Todo ser humano tem dignidade. É pessoa. Tem sentimentos, tem sonhos e projetos. O silêncio de Onésimo denuncia algo que é forte nas narrativas da tradição bíblica. Os "da margem” quase nunca têm voz. Também Onésimo não é protagonista. Com isso, só podemos suspeitar que, no fundo do seu coração, o sofrimento interior era enorme. Cada pessoa que é mutilada nos seus planos, esconde, entre outros anseios, a tristeza de não poder fazer quase nada pelos seus (filhos/as, parentes próximos etc). É ensurdecedor sentir que é aviltado na sua própria vida e que pessoas próximas a ele, também, devem estar na mesma situação. O drama interior do escravo Onésimo é silenciado no Bilhete a Filêmon.

d) Uma questão forte que se coloca é o v. 10 que diz: "venho suplicar-te em favor de meu filho Onésimo, que gerei na prisão". Este versículo, por mais bondosa e corajosa que tenha sido a atitude de Paulo, denuncia o espírito patriarcal da época. Claro que Paulo estava se referindo ao filho, na fé. Portanto, ele era o seu pai, na fé, como, em outra oportunidade, ele havia se referido aos coríntios, como gerados, em Jesus Cristo, por ele (1 Cor 4,15). Decodificando, pode-se fazer uma analogia com o filho biológico. O Apóstolo toma a iniciativa e fala como qualquer patriarca de todos os tempos. O filho, gerado na prisão, Onésimo, não tinha voz e, muito menos, vez. Ele era escravo. Não tinha espaço. Foi gerado. Onésimo, dentro da sociedade greco-romana, recém-gerado, não podia ter 
iniciativa. Era o pai quem tinha que agir por ele. O pai era Paulo. Será o "papai” quem o enviará de volta para Filêmon (v. 12). A relação de poder foi vertical, bem ao estilo romano.

Como já se viu, o Bilhete a Filêmon foi escrito a partir da ótica de quem detinha o "poder", ou seja, Paulo. Tanto detinha, que havia trabalhado pela conversão de Filêmon, um patrão. Se era senhor, estava conscientemente ou não, ligado ao modo de produção escravagista romano. Paulo, uma "autoridade" falou a um pequeno "poderoso" (Filêmon) em prol de um que estava abaixo da pirâmide (Onésimo). Esta reflexão não quer desmerecer Paulo. Porém, ela quer escutar aquele que "vegetava" dentro do sistema romano, que parecia que não tinha consciência, ou seja, o "escravo", que estava abaixo da base.

\subsection{Perspectiva cultural, militar, androcêntrica e jurídica}

No aspecto "jurídico”, no tempo dos cristianismos originários, havia várias categorias de escravos, no sistema governamental romano: 1) Os que trabalhavam nas grandes propriedades agrícolas, habitualmente, moravam perto das sedes; 2) Os que trabalhavam nas minas e nas pedreiras: viviam em situações piores que os demais escravos; 3) Os “escravos públicos": dentre esses, haviam aqueles que eram até pedagogos e, por vezes, estavam em bom nível intelectual ou cultural; 4) os "funcionários" da cidade ou do imperador: serviam em atividades bem variadas. Se alguns, de bom nível, trabalhavam em funções administrativas, outros desenvolviam trabalhos pesados, como a manutenção dos banhos públicos e dos aquedutos. 5) Os "escravos domésticos": dependiam muito do humor dos seus senhores e das tarefas que lhe eram confiadas (FERREIRA, 2005, p. 109-110)8 ${ }^{8}$

No direito romano, a condição de escravo podia ser o castigo de certos crimes (HOPKINS, 1978, toda obra). Quem eram os escravos? Havia vários tipos:

\footnotetext{
${ }^{8}$ São interessantes essas informações jurídico-sociais, porque nós, do Brasil, anacronicamente, podemos olhar os escravos romanos com o olhar das experiências ignominiosas da escravatura brasileira, quando, para aqui vieram, milhares de seres humanos provenientes da África.
} 
1) Escravos por nascença; 2) Por serem prisioneiros de guerra; 3) Vendidos por seus pais; 4) Por se venderem para pagar dívidas. Em todo o império havia mercado de escravos (FERREIRA, 2005, p. 109).

Parece, pelos dados do Bilhete a Filêmon, que ele se enquadrava no item “escravos domésticos”. No aspecto “cultural e androcêntrico” é preciso compreender que a civilização grega, naquele tempo, se infiltrou pela penetração cultural, intelectual e filosófica, especialmente, no Ocidente. Enquanto isso, a dominação romana se impôs pela força militar e policial para salvaguardar a política, a economia e a "ordem social”. Roma respeitava as culturas autóctones, bem como suas religiões. No entanto, quanto ao controle econômico e administrativo, ela era muito severa com os povos dominados. Daí, advinha uma penetração inconsciente, por parte dos colonizados, de que a escravidão fizesse parte da história dos dominados. Isso acontecia, especialmente, com colônias mais próximas do centro do império e com mais tempo de submissão.

A visão "patriarcalista” era típica, tanto na Grécia (cultura) como em Roma (domínio) bem como em quase todo o império. O masculino dominava o feminino. Nesse sentido, no Bilhete a Filêmon, a presença de Ápia é digna de atenção. O nome de uma mulher, por escrito, numa sociedade "machista" violava o tradicional. Isso estava dentro da linha de Paulo. O endereçamento a uma mulher (também dominada) foi algo bem positivo. Possivelmente, esse dado do feminino tenha, também, chamado a atenção de Onésimo.

\subsection{Perspectiva social: conversão de Filêmon, Onésimo e Paulo}

A partir do texto a Filêmon, detecta-se o dinamismo da vida daquela gente dentro da sociedade, possivelmente, em Éfeso na Ásia Menor, dentro do império romano. Os autores foram Paulo Apóstolo e Timóteo (v. 1a). No final (v. 23-24) há uma referência a Epafras, que, parece, estava, também, na prisão. Alude-se, também, a Marcos, Aristarco, Demas e Lucas. Era um grupo de evangelizadores. 
Não fica claro se os quatro últimos estavam presos. Além deste grupo que escreveu ou enviou o Bilhete, vê-se claro, o grupo dos receptores: o bilhete, além de dirigirse a Filêmon, foi endereçado também a Ápia, a Arquipo e a toda a ekklesía que se reunia na casa de Filemon. O Bilhete tinha uma proposta comunitária.

Na cadeia, por incrível coincidência, Paulo e Epafras, talvez, também, Timóteo ficaram presos junto a um escravo do coordenador de uma comunidade cristã fundada pelo missionário Apóstolo. Esse animador da comunidade se chamava Filêmon. Se tinha escravo, era porque estava num nível de bens (proprietário) e de poder.

Então, aqui temos, claramente, algumas contradições sociais. Na prisão, estão pessoas ligadas à condução da ekklesía, portanto, autoridades: Paulo, Timóteo e Epafras. Foram presas por causa da luta por um ideal: Jesus Cristo. Junto a eles, o desumanizado Onésimo: escravo e castigado. Pelo Bilhete, fica-se sabendo da "casa” (oikía) de Filêmon, um convertido. Era um senhor que tinha escravos. Portanto, vivia, tranquilamente, dentro do esquema dos modos de produção escravagista romano.

Do lado de Filêmon, a sociedade estava estável. Não se devia mexer em nada. Era uma visão "funcionalista”. Do lado de Onésimo, a sociedade estava em tensão: como entender a escravidão? Como compreendê-lo como escravo? Onésimo sentia a contradição na pele.

A "grande" sociedade greco-romana era controlada por um "pequeno" grupo de poderosos. Isto é, centenas e centenas de colônias eram dominadas pelo império. A economia e a política se moviam através dos "modos de produção escravagista”. Aí dentro, a figura de um escravo, sem voz, sem vez, sem espaço.

Roma tinha tanto domínio, pela força e pela ideologia, sobre os escravos que era quase impensável qualquer organização por parte daqueles que estavam abaixo 
da pirâmide9 . Todo grupo tende a conseguir seus próprios objetivos, protegendo os interesses específicos de seus membros. Ora, Onésimo não tinha grupo, não tinha o que defender, em nível de interesses específicos. Era escravo. Era mutilado. Esse era o "lugar social” do escravo Onésimo.

Agora, nesse momento, olhando pela ótica do escravo Onésimo, é preciso colocar bem clara uma questão: Filêmon, num primeiro momento, estava dentro do esquema dos modos de produção escravagista romano. Ele era senhor e patrão. Paulo, também, estava num nível de super estrutura. Claro! A igreja ainda não era uma força poderosa. Entretanto, naquele momento, Paulo era alguém que estava, sociologicamente falando, acima do universo do escravo Onésimo e do grupo de Filêmon.

Não chegava a ser uma pirâmide de relações de poder. No entanto, Paulo era "ponta de lança” nos cristianismos originários. Era um missionário que já havia evangelizado e aberto a proclamação da Boa Nova às muitas nações dentro do império greco-romano. Ele era um referencial na ekklesía. Então, Filêmon, bem como Ápia, Arquipo e a Igreja (receptores da missiva) e Paulo com Timóteo (escritores da mesma) estão num nível bem acima de Onésimo. Estes dois fizeram a interlocução. Mandaram saudações, portanto, tiveram voz Epafras, Marcos, Aristarco, Demas e Lucas (vv. 23-24).

Parece estar claro: as relações de Paulo com a "casa" de Filêmon foram verticais. No Bilhete oficial, Onésimo era o objeto, porém, passivo. Ele não teve participação nenhuma.

Porém, a leitura pelo método sociológico pelo modelo conflitual/ contradição não vê assim. Possivelmente, Paulo, Epafras e, talvez Timóteo, tenham refletido com Onésimo sobre as contradições sociais no mundo grecoromano, especialmente, sobre a distância descomunal entre os "livres e escravos"

${ }^{9}$ Roma reprimia qualquer revolta. É bom lembrar que, não muito tempo antes, de 73 a 71 a.C., houve a Guerra dos Servos e a Revolta de Espártaco. No final, a força militar romana expôs 6.000 escravos crucificados ao longo da Via Ápia. 
(BRADLEY, 1987, toda obra), entre os “ricos e pobres”. Eles não sabiam, mas, hoje, nós sabemos que dois terços da população eram de trabalhadores remunerados e de escravos. Um terço da população era de homens livres e libertos de todas as partes, principalmente, helênicos e romanos. Dentre os poucos ricos, estavam os pertencentes ao sistema “patronal” romano e à elite grega. Onésimo deveria ter dificuldades para entender as informações em torno do jugo romano e suas injustiças com as colônias e seus milhares de habitantes.

Provavelmente, falaram sobre a ekklesía, talvez de Éfeso. Aqui, puxando para o seu lado, Paulo e seus amigos devem ter falado da riqueza comunitária da Igreja que se reunia na oikía (casa) de Filêmon. As reuniões eram sempre nas casas. Aí, a conversa deve ter entrado na questão das presenças femininas em toda a Igreja. Isso deve ter impressionado Onésimo, pois ele sabia que as mulheres eram discriminadas em todos os segmentos, inclusive, no religioso. Ouvir falar de Ápia e outras tantas mulheres deve ter sido fascinante para ele. Uma nova esperança deveria ir surgindo na cabeça do escravo. Se as mulheres estavam ocupando um novo espaço, também os escravos deveriam ocupar.

É necessário observar que o convertido Filêmon pertencia a uma classe social dos livres e o seu relacionamento com os escravos era determinado pelo "modo de produção" econômica do esquema romano. Portanto, explorar o escravo Onésimo era tranquilo. Não afetava a sua consciência. Possivelmente, a “conversão” de Filêmon ainda estava no nível da religião descomprometida.

Até então, os conflitos entre Filêmon e Onésimo foram de senhor para escravo. O senhor (patrão) meteu na cadeia o escravo que lhe deu prejuízo. Não interessava mais a vida de Onésimo, se é que ele tinha nome diante do senhor Filêmon.

Já Onésimo, no Bilhete, foi passivo e silenciado. Ele não tinha espaço no universo eclesiástico e, muito menos, na esfera do império e, menos ainda, na “casa” de Filêmon. Ele era o personagem mais importante do Bilhete, porém, não 
era protagonista. O que o "marginalizado", na prisão, teria falado nesse nível social?

\subsubsection{Questões prováveis colocadas por Onésimo}

Certamente, o assunto "escravo" foi a tônica que fez "converter" o escravo. Onésimo não teria questionado a pregação, o pregador e a contradição do seu exsenhor? Ele deveria insistir: "como é Paulo, que você fala tanto na liberdade, em nome de Jesus, e, no entanto, o meu patrão é cristão e tem, ao mesmo tempo, escravos"? "Que religião contraditória é essa”? "Paulo, enquanto eu era escravo na casa de Filêmon, eu o via nas reuniões comunitárias falando sobre Deus, louvandoo e sentia, no dia a dia, o peso do escravagismo". "Paulo, eu não entendo"!

Suspeita-se que Paulo foi atingido, no centro da consciência, por essas conversas do interno da prisão. Paulo, também fragilizado, velho e preso (v. 9), após tanta evangelização pastoral, deve ter sido tocado pelas conversas do escravo Onésimo. Aí, não se tem dúvida, Paulo começou a lhe dar esperanças de uma solução. Onésimo deve ter se entusiasmado quando Paulo lhe afirmara que iria pedir ao seu ex-senhor que lhe perdoasse, o recebesse e o colocasse dentro de sua família (vv. 10-12).

A conversa entre os prisioneiros deve ter chegado no nível profundo da afeição e ternura, porque o Bilhete a Filêmon estava carregado dessas sensibilidades: receba-o "não mais como escravo, mas muito além de escravo, como irmão amado. Para mim ele é um irmão muito amado, e ainda mais para você, tanto como pessoa quanto como cristão. Assim, se você me considera como amigo, receba-o como se estivesse recebendo a mim mesmo” (vv. 16-17). Então, na convivência da cadeia, Paulo, também, se converteu para uma luta por um excluído. Esse embate foi além do cárcere, quando a missiva foi endereçado a um cristão/senhor, que também, na mentalidade e na prática, deveria se converter: Filêmon deverá sair do esquema escravagista romano e experienciar a liberdade 
para com os seus ajudantes. Teria Filêmon outros escravos/as, além de Onésimo? Se sim, esses não serão mais escravos e sim trabalhadores. Mais ainda, partícipes da família e da igreja. Estava acontecendo uma transformação da ternura. Com isso, a partir da prisão, a exclusão social de Onésimo estava sendo superada e a mentalidade de senhorio, típica da visão romana, estava sendo rompida.

A imagem da "pirâmide" social e econômica estava dando lugar à figura "circular", onde todos/as estavam no mesmo nível, a partir do Evangelho. O explorador estava compreendendo a novidade e, com isso, as contradições, tensões e conflitos, no modo do esquema romano, estavam cedendo à mentalidade de uma fraternidade cristã.

Esse grupo de Filêmon, agora também com Onésimo deixará de existir no esquema do imperialismo romano e experimentará a prática cristã do igualitarismo e da liberdade. O grande conflito das assimetrias estava sendo superado, pelo menos, na prática, na comunidade de Filêmon, Ápia, Arquipo e toda a igreja. O senhor se igualava, do mesmo modo, ao ex-escravo. A utopia estava sendo realizada.

\subsection{Perspectiva econômica: dívida e perdão}

Os vv. 18-19 evidenciaram uma questão econômica, típica do modo de produção escravagista romano, isto é, a questão do “credor-devedor”. Todo sistema romano se movia dentro dessa bipolaridade. As colônias estavam, sempre, debaixo da estrutura do débito para com o centro das decisões, a cidade de Roma. As colônias, querendo ou não, sempre estavam em débito. Era assim que funcionava o jogo econômico financeiro do império. Ora, quando Paulo usou o conceito financeiro "crédito-débito" ao senhor Filêmon, estava reproduzindo a terminologia chave do escravagismo. O escravo Onésimo era a representação de todos os outros escravos. 
Outra coisa que o texto deixa transparecer: o endividado. O escravo tinha dívida. Era um problema entre ele e o antigo patrão, Filêmon. Como foi colocado antes, se Paulo tocou na questão da dívida, ter-se-á que perguntar: que dívida era esta?

A dívida, dentro do esquema do império, era um obstáculo, até para quem não era escravo. No nível dos livres, negociam-se as dívidas. Porém, no nível do escravo/senhor, não há o que negociar. O escravo não tinha voz e nem espaço para esse tipo de relação. Aqui tivemos, dentro do modo de produção escravagista, um "meio de produção" que era a causa da prisão do escravo. Parece, sim, que ele teria furtado ou dado prejuizo ao patrão. Ora, na convivência do escravo com Paulo e Epafras, dentro da cadeia, acharam um modo de superar aquele empecilho: a dívida seria paga por Paulo.

Só que aí surge uma outra questão: dentro da cadeia, o escravo não colocava a Paulo a sua revolta contra as injustiças da escravidão? De onde era aquele escravo? Será que ele não vinha de alguma região onde o povo era livre antes da chegada dos invasores romanos? O que moveu Paulo a se inclinar pelo anseio do escravo? Foi, de fato, o amor ao Evangelho que dizia que era "era para a liberdade que Cristo nos libertou" (Gl 5,1.13) ou, ainda, "não há mais escravos nem livres" (Gl 3,28)? Ou, além disso, não foi, agora, com os pés e todo o corpo na prisão, no diálogo com o escravo humilhado, que Paulo percebeu que era o momento de colocar em prática a ruptura com o sistema escravagista?

O fato é que Paulo, na conversa, por escrito, com o patrão Filêmon, foi mostrando que o diálogo estava no nível que visava o "lucro". Se ele, Paulo pagasse pelo escravo ("eu pagarei": v.19) a visão econômica do lucro continuaria. A bipolaridade "credor-devedor" permaneceria e o sistema continuaria, sem contestação. Ou seja, Filêmon recuperaria o prejuizo e nada seria questionado.

A imagem massacrante do "devedor" econômico foi substituida por outra imagem: o "devedor" existencial (v. 19c). Filêmon era devedor de Paulo, no nível da fé. Foi a partir daqui que ele redescobriu a existência e passou a viver de um 
modo novo na ekklesía. Agora, era possível mudar o conceito de compreensão da dívida. Falar de dívida econômica, no nível de comunidade de Jesus Cristo, naquele momento, não tinha sentido algum. A imagem muda, também, a visão da economia do império.

Da dívida, saltou-se para outro conceito: o perdão. Então, Paulo fez ver a Filêmon que ele, também, era “devedor" de Paulo. O débito, agora, muda, radicalmente, a visão do patrão. Ele devia a Paulo, exatamente, a nova vida. Ele era convertido. Ele não podia estar no nível da visão imperial romana. Ele deverá compreender o perdão das dívidas, no sentido bíblico (Dt 15,1-11; Lv 25,8-16), para entender a nova liberdade: a sua (Filêmon) e a do escravo (Onésimo). O lucro não terá lugar nesse novo modo de experiência comunitária.

Escutando o escravo, Paulo clareou, no concreto, a questão da liberdade. Por isso, tomou uma atitude transformadora. De novo, é preciso se colocar no lugar do escravo. Não teria ele, na conversa, sem fim, dentro das grades da cadeia, escutando Paulo e Epafras, colocado questões nessa linha das dívidas? Certamente, Paulo não tinha todas as ideias claras e a visão da totalidade da liberdade. Na conversa, na reflexão a dois ou três, o pensamento foi se clareando. A experiência com alguém da "margem" transformou Paulo. Se Paulo, deveras, vai fazer uma proposta revolucionária a Filêmon era porque, no bate-papo, o assunto foi sendo amadurecido. Possivelmente, o silenciado Onésimo teve uma participação ímpar naqueles momentos. Já que Paulo aproveitou para fazer catequese envolvendo o escravo (meu filho Onésimo, que gerei na prisão: v. 10), certamente, Paulo deve ter aprendido muito porque precisava ouvir também e sentir as angústias de um mutilado na liberdade. 


\subsection{Perspectiva política: a realidade da margem provocava a transformação}

Tanto as leis como a política eram baseadas no modo de produção escravagista romano (GIORDANI, 1981, toda obra). O patronato romano, em qualquer parte, representava o império (CHOW, 2004, p. 111-129) ${ }^{10}$. Este respeitava a cultura e os costumes de cada colônia, desde que não houvesse insubordinação contra Roma, nos níveis econômico e político (WENGST, 1991, toda obra). Não se sabe em que cidade Paulo e Onésimo estavam presos. Parece que a prisão se dera na cidade de Éfeso. Que dados nos levam a entender a política do Bilhete a Filêmon?

A prisão: Nos vv. 1, 10, 13, 23 usa-se a terminogia "prisão". Onésimo estava, por duas vezes, desumanizado. Primeiro, como escravo. Uma tragédia! Depois, como preso, não por uma causa idealística, mas por castigo. Um vexame!

O v. 2 fala de Arquipo, como companheiro de "lutas". O termo "companheiro" é usado, também, no v. 23, referindo-se a Epafras. Os vv. 11-12, dizendo do "inútil" e "útil" retrata o valor de uso transformador. Os vv. 13-14 espelham a ideia de necessidade e liberdade. Paulo não se impôs a Filêmon, porém, o deixou à vontade para decidir. Vê-se no Bilhete que Paulo foi muito hábil, muito diplomata. Em um momento, ele usou de uma "boa chantagem" na técnica do convencimento.

Os vv. 15-17 expressam a a ideia da partilha e a nova ordem social. O modo como o termo agápe (amor) é inserido no texto, demonstra como, em nível político, deverá ser a nova comunidade (vv. 577.9.16a.16b) que superará a assimetria senhor/escravo. Também, o termo "irmão" (adelfós) (7.16a.16b. 20) reflete essa postura transformadora. Quer dizer que a "prisão" foi o local onde o "lugar social" dos encarcerados veio à tona. Temos aí, as figuras de Paulo e

\footnotetext{
${ }^{10}$ Chow apresenta a pirâmide romana manifestando-se assim: na ponta, o "imperador". Depois, a "ordem senatorial". Um pouco abaixo, o "patronato" que era o grupo social mais importante. Em seguida, a "ordem equestre". Após esta, os "cavaleiros publicanos" (plebeus enriquecidos). Depois, os "clientes": plebeus na dependência de uma família rica e poderosa. A seguir, os "plebeus" homens do povo que não eram nobres. Lá embaixo, os "livres" e, bem embaixo, os "escravos".
} 
Timóteo que foram presos por um ideal: a proclamação do Evangelho (v. 1.9) e a pessoa de Onésimo, sem ideal. Está sendo castigado (v. 10-12.18). Na prisão, o mais fraco, Onésimo, foi encontrado. Porém, não seria de se perguntar se não foi o escravo Onésimo quem converteu Paulo? A realidade da margem provoca sempre.

Aqui se deve perguntar: não estaria o escravo Onésimo, no diálogo, incessante, com Paulo, questionando as ideias do cristianismo originário principalmente, em torno das ideias de companheirismo, fraternidade e amor concreto? Por que será que Paulo decidiu mandar o bilhete a Filêmon? Onésimo não interrogava a Paulo: "por que eu estou preso, porque eu sou escravo, se Filêmon é cristão e me subjuga nos moldes dos romanos"? "Pode um cristão ter escravos"?

Por conseguinte, é de se supor que, nas conversas, Paulo viu que era hora de agir, na práxis, diante de um ser humano que estava na cadeia, possivelmente, por causa de injustiças do sistema "senhor/escravo".

Uma coisa é pregar (teoricamente), sobre a "liberdade" como Paulo fêz aos Gálatas (3,28; 5,1.13), aos Coríntios (1 Cor 12,13; 2 Cor 8,13-14), aos Romanos (6,15-19). Para bem da verdade, Paulo buscava atualizar suas pregações. Por exemplo, em 2 Cor 8,12-13, ele fez uma proposta real de igualdade. Foi nessa mentalidade, que ele organizou uma coleta (1 Cor 16,1s; Rm 15,26-28; Gl 2,10) para os desabrigados de Jerusalém. Além disso, foi aqui na prisão que ele viu que era hora de agir (concretamente) diante de um fato real acontecido com ele e um escravo. É de se pensar que ouvindo e entendendo o ponto de vista do escravo Onésimo, Paulo discerniu que chegara a hora de tomar uma posição. Esse passo político de Paulo foi fundamental para as futuras gerações cristãs. O lado político faz o leitor, ler, por trás das palavras, o religioso encarnado na realidade.

Vai se percebendo que houve uma subida "degrau a degrau", por parte do Apóstolo, na experiência da prisão, no diálogo tranquilo e sem ansiedade, com o escravo. Por exemplo, a postura teológica de Paulo, sobre a liberdade, na Epístola 
aos Gálatas, foi impetuosa. Paulo, naquela missiva, comunicou-se em "trovoadas". Ele estava intempestivo e indignado. Por conseguinte, as assertivas "é para a liberdade que Cristo nos libertou" (Gl 5,1) e "vós, com efeito, fostes chamados à liberdade, irmãos" (Gl 5,13) foram conceituações teológicas do mais alto nível, que têm sido fundamentos para todas as gerações cristãs que lutam pelo fim da escravatura. Porém, foram colocadas em níveis conceituais.

Aqui, em Filêmon, não. O texto de Paulo reflete um homem humilde, delicado e com uma linguagem bem afável e até diplomática. Por trás da linguagem, vê-se que ele foi, também, adequando os seus conceitos teológicos sobre a liberdade. A adequação o levou a uma atitude concreta. A liberdade conceitual tornou-se, radicalmente, encarnada. Foi o "velho" e "prisioneiro" quem falou (v. 9), por "amor" (v. 8) pedindo a "liberdade" (v. 8) de Onésimo. Ele estava sendo devolvido não mais como "escravo”, mas como um “irmão amado” (v. 16).

\subsection{Perspectivas ideológica e religiosa: o "anúncio incomodava"}

O Bilhete a Filêmon tem cargas "ideológicas" e "religiosas" bastante acentuadas"11. A palavra "prisioneiro", já no início, e repetida junto à palavra "prisão" (v. 1.9.10.13.23) denuncia o sistema romano que tolhia a liberdade de quem apresentasse alguma ideologia contrária aos interesses do império. A estrutura absolutizada do governo imperial estava, por trás desses conceitos, sendo criticada e denunciada.

Os adjetivos referentes a dois personagens do grupo de Paulo acenam que o Evangelho era algo que o sistema romano não suportava. Ao se referir a Arquipo (v. 2) como "companheiro de lutas" e a Epafras, meu "companheiro de prisão por causa de Cristo Jesus", percebe-se, por parte do autor, que o anúncio de Jesus Cristo incomodava as forças imperiais. Em 1Cor 4,9 Paulo já havia escrito que o

\footnotetext{
${ }_{11}$ Para se ter as informações, olhando do outro lado, o de Roma, sugere-se a obra Vida e Religiões no Império Romano no Tempo das Primeiras Comunidades Cristãs (COMBY; LEMONON, 1981).
} 
sistema romano não suportava a evangelização: “Julgo que Deus nos expôs, a nós, apóstolos, em último lugar, como condenados à morte: fomos dados em espetáculo ao mundo, aos anjos e aos homens”. O cristianismo originário estava encarnado nas conflituosas tensões do império romano, a exemplo do crucificado.

O termo "irmão" (adelfós) que aparece quatro vezes (v. 7.16a.16c, 20) era algo determinante nos cristianismos originários. Por trás da palavra, estava a força agregadora das primeiras comunidades que se organizavam, não dentro de "pieguices", mas para um projeto novo.

A palavra "amor" (agápe) e "amado" foram, por parte do autor, o centro de toda a missiva (v. 5.7a.7c.9.16a. 16c.). Num império onde o egoísmo e o lucro dominavam as relações humanas, essa palavra foi uma proposta revolucionária.

Embora, ao lermos o Bilhete a Filêmon como um texto que silenciou Onésimo, pois esse era o estilo de Paulo, no entanto, todo o Bilhete teve a preocupação com a pessoa humana. Onésimo não era escravo, não era “coisa”. Era gente. Por ele, devia-se lutar.

Por fim, a expressão "Cristo Jesus" e "Senhor Jesus Cristo" abriram (v.1) e fecharam (v. 25) a missiva. Todo o sentido de vida de Paulo, o seu grupo e os cristianismos originários aparecia na pessoa de Jesus Cristo. Era, por causa dele, toda a evangelização e proposta de algo novo, dentro do império romano e civilização grega. Os interesses dos cristãos foram defendidos com ardor, a ponto de levar um grupo expressivo para a prisão. A nova religião comprometia: quem aderisse a ela corria o risco de ir para a prisão e para a morte.

\subsubsection{Compreensão da Palavra}

Dentro desse sub-tópico, é preciso entender a compreensão da Palavra de Deus diante do movimento econômico, social, jurídico, político, cultural, 
ideológico/religioso que dinamiza o texto. Olhando com os olhos do autor (Paulo), vê-se, claramente, como a experiência comunitária e de fé é descrita no Bilhete.

Na cabeça de Paulo não havia lugar para a escravatura. Esse não era o espírito da comunidade cristã. Todas as relações humanas deveriam, dentro do sistema imperial, serem mudadas (CAÑAVERAL,1995, p. 46-50). Tranquilamente, dentro do cárcere, Paulo pode evangelizar e, ao mesmo tempo, escutar o escravo. Por isso, ele, também, foi evangelizado.

O Paulo autoritário de outras cartas, algumas vezes de posição fechada, deve ter se revisto seriamente. No ambiente de prisão e cadeia não se pode permanecer com "fixidez absoluta". Então, ao se referir a Onésimo como "irmão amado" e "irmão muito amado" (v. 16a.16c), o autor soube dizer ao pobre (escravo Onésimo) que Deus o amava e soube dizer ao rico (Filêmon) que Deus, também o amava, tanto que deverá haver uma transformação radical na casa do patrão. Foi sintomático, como percebeu Wegner (1997/3, p. 87-89), que a agápe construia a comunidade.

Paulo, nas conversas de vozes baixas da cadeia deve ter escutado o "clamor" de Onésimo, tendo empatia total com ele. Está muito claro no bilhete. O autor fêz de tudo para libertar o escravo. Talvez, dentro da cadeia, Paulo, sem sair do local, tenha caminhado mais do que muitas de suas viagens anteriores. Aqui na prisão, a pequena ekklesía caminhou na direção concreta da libertação da escravatura, por quilômetros e quilômetros. O Paulo do Hino Batismal (Gl 3,26-28) que disse que não havia mais "escravos e livres", o Paulo defensor da Liberdade (Gl 5,1.13) agora se deparou, concretamente, com um caso que exigia uma atitude, em nome da fé em Jesus Cristo. Ele estava convivendo, dialogando e ouvindo um escravo. O Apóstolo fez um apelo à casa de Filêmon, partindo do "escravo". Ele viu, de fato, Jesus Cristo na carne de Onésimo. Era hora de "por em prática" o que se cantava e pregava sobre a liberdade. 
No meio do dinamismo histórico, o Bilhete retratou como as comunidades (grupos de Paulo) conseguiam enxergar o Deus da Vida que trazia algo novo para elas. A “casa” de Filêmon ao receber Onésimo estará se transformando, radicalmente. Depois, ela deverá, também, receber Paulo (v. 22) que se abrigará no "aposento". O coordenador das comunidades vivenciará a mudança, em Jesus Cristo.

\section{Conclusão: Jesus Cristo na carne de Onésimo}

Reconstruindo o texto do Bilhete a Filêmon, a partir da leitura sociológica pelo modelo conflitual/contradição, percebem-se as contradições da sociedade e das pequenas comunidades, as resistências e lutas, as opressões e libertações. Essa leitura procurou olhar a sociedade como estrutura em tensão. Aí dentro, também, grupos em dinâmica.

Ora, biblicamente e historicamente falando, a questão da escravidão sempre teve, por parte de "grupos da margem", a reprovação absoluta e a busca da liberdade, em nome da Palavra de Deus. Pelo que se viu, suspeita-se que Onésimo, o escravo, foi um questionador do colega de prisão, Paulo. Ao conscientizá-lo de que as teorias do "não há escravo nem livre" (Gl 3,28b), de "é para a liberdade que Cristo nos libertou” (Gl 5,1.13), concretamente, a questão da liberdade, para valer, deveria ser realizada na pessoa dele, Onésimo. Ele, ao compreender a proclamação do Evangelho na cadeia, deve ter cobrado do evangelizador, de fato, se ele, Onésimo, não deveria se tornar "livre". A paternidade de Paulo ao novo filho Onésimo (v. 20) deve ter sido resultado de muito questionamento nas infindáveis conversas dentro do cárcere. Ouvindo Paulo falar que, a partir de Cristo, havia transformações étnicas, de gênero e social, Onésimo deve ter compreendido bem, porém, deve ter exigido, na prática, que isso deveria acontecer com ele. Assim, Onésimo, um homem da "margem" deve ter ajudado a criar uma identidade transformadora e tornou-se um agente de uma nova sociedade: a casa de Filêmon, 
a partir de agora, não poderá ser a mesma. Os escravos, além dele, teriam que ser libertados.

No meio das contradições agudas, a pequena comunidade orientada por Paulo e coordenada por Filêmon tomou força para apresentar o projeto do Deus Vivo. A liberdade foi concretizada. Para se ter certeza de que a "casa" de Filêmon realizou a libertação do escravo e, possivelmente, de outros, está o fato de o documento (Bilhete a Filêmon) ter entrado para o cânon bíblico. O agora livre

Onésimo, mais tarde, após a morte de Paulo Apóstolo, foi citado na Epístola dêuteropaulina aos Colossenses ( $\mathrm{Col}$ 4,9), como "nosso querido e fiel irmão, e que pertence ao grupo de vocês”.

Assim, a partir da "margem" procurou-se entender como que uma das questões mais intrincadas, enfrentadas pela Bíblia (a situação da escravidão e a realização da liberdade), tornou-se possível quando, o orientador maior da comunidade, no cárcere, ao conviver e escutar um escravo, conseguiu realizar a virtude da empatia e, convertido, lutou pela sua libertação. Assim, uma identidade transformadora foi se tornando uma das características dos cristianismos originários. Paulo teria encontrado um Jesus Cristo concreto na carne do escravo Onésimo.

\section{REFERÊNCIAS}

ALVAREZ-VERDEZ, L. El Método Sociológico en la Investigation Bíblica Actual. StMor, n. 27, p. 5-41, 1989.

BRADLEY, K. R. Slaves and Masters in the Roman Empine. A Study in Social Control. New York, Oxford : Oxford University Press, 1987.

CAÑAVERAL O. Aníbal. Carta a Filemón. Una respuesta a las ansias de libertad. Santa Fé de Bogotá: CEDEBI, 1995. 
CHOW, J. K. Patronato na Corinto Romana. In: HORSLEY, R. A. (Org.) Paulo e o Império: religião e poder na sociedade imperial romana. S. Paulo: Paulus, 2004, p. 111129.

COMBLIN, J. A Mensagem da Epistola de São Paulo a Filemon. Estudos Bíblicos. Petrópolis, n. 2, p. 66-70, 1987.

COMBY, J.;LEMONON, P. Vida e Religiões no Império Romano no Tempo das Primeiras Comunidades Cristãs. São Paulo: Ed. Paulinas, 1988.

FERREIRA, Joel A. Primeira Epístola aos Coríntios. São Paulo: Fonte Editorial, 2013.

FERREIRA, Joel A. Gálatas: A Epístola da Abertura de Fronteiras. São Paulo: Loyola, 2005 .

FERREIRA, Joel A. Não há escravo nem livre (Gl 3,26-28b): superação da assimetria social. Fragmentos de Cultura. Goiânia, vol. 12, n. 4, 2002, p. 717-738.

FERREIRA, Joel A. Paulo, Jesus e os Marginalizados. Leitura Conflitual do Novo Testamento. 2.ed. Goiânia: Ed. da PUCGoiás, 2011.

GIORDANI, M. C. História de Roma. Petrópolis: Vozes, 1981.

GRANT, Michel. O Mundo de Roma. Rio de Janeiro : Ed. Arcádia Limitada, 1960.

HOPKINS, Keith. Conquerors and Slaves. Sociological Studies in Roman

History. Cambridge : Cambridge University Press, 1978.

MALINA, Bruce J. Christian Origins and Cultural Anthropology: Practical Models for Biblical Interpretation. Atlanta : John Knox, 1986.

MÍGUEZ, Nestor O. Escravos no Império Romano: o caso de Onésimo. RIBLA, Petrópolis, n. 28, p. 90-98, 1997/3.

OSIEK, Carolyn. The New Handmaid: The Bible and the Social Sciences. Theological Studies, Baltimore, n. 50, p. 260-278, 1989.

ROSTOVTZEFF, M. História de Roma. Rio de Janeiro : Zahar Editores, 1967.

WEGNER, Uwe. Comunidade e autoridade em Filemon. RIBLA, Petrópolis, n. 28, p. 80$89,1997 / 3$.

WENGST, K. Pax Romana. São Paulo: Paulinas, 1991. 